DOI: 10.20472/IAC.2018.035.012

\author{
HENRYK DŹWIGOt \\ Silesian University of Technology , Poland
}

\title{
QUANTITATIVE METHODS IN THE TRIANGULATION PROCESS
}

\begin{abstract}
:
The following article presents an analysis of selected quantitative methods in the research process. The author highlighted the importance of quantitative analysis in the research process, which requires to collect a great number of data, as well as to analyse and interpret them. Selected research methods were stipulated: SPACE (Strategic Position and Action Evaluation), network methods and the Delphi method. An analysis of the use of triangulation method in order to enhance the reliability of research results was carried out.

The Author attempted to answer the following research questions: What research methods should be employed in the research processes within the area of economics? Is the methodological triangulation a prerequisite in research processes? Does the triangulation enhance the reliability of employed quantitative methods in research processes?
\end{abstract}

\section{Keywords:}

method, methodics, research process, triangulation, quantitative methods

JEL Classification: B40, C10, C00 


\section{Introduction}

A method may be defined as a premeditated way of action, allowing to achieve a desired goal (Sudoł, 2007, p. 123). On the other hand, Sztumski J.(Sztumski, 2005, p. 212) defined a method as „a system of rules and assumptions that facilitate such an ordering of theoretical or practical actions in order to achieve a consciously defined aim". It is a research procedure or a research process. A researcher should put a particular emphasis on creating correct research methodics, while distinguishing basic notions used in the management sciences and economics.

In order to discuss methods necessary for execution of scientific research related to economics, one needs to define basic notions. Among basic notions, one might include research methods, research processes, classification of research methods or method triangulation.

The essence of triangulation is to employ two or more methods to compare obtained findings and draw conclusions from the applied methods. It is perceived as a good practice to combine qualitative and quantitative methods (Kostera, 2003, p. 97). Since the triangulation defines, assesses and analyses the reality from different angles, it is a reasonable solution to use methods taken from two different areas. The said approach to the research is called: a complex (Gerstmann, 1987), complementary (Szałkowski, 1997) or poly-methodical (Płoszajski, 1985) one.

Research questions:

- What research methods should be employed in the research processes within the area of economics?

- Is the methodological triangulation a prerequisite in research processes?

- Does the triangulation enhance the reliability of employed quantitative methods in research processes?

In this article the Author attempted to analyse the importance of selected quantitative methods in the research process as well as method triangulation. He carried out research as to the elaboration of an optimal selective method, in order to enhance the reliability of findings in the area of economics.

The presented thoughts derive from works published by many outstanding and renowned researchers in the area of economics. The Author, on the other hand, has been attempting, for some years, to find and examine optimal research methodics, processes and procedures in the area of economics and management sciences. 


\section{Quantitative methods in the research process}

Among the methods which, regardless of any methodological changes, enjoy a steady popularity, one can distinguish the simplest statistical techniques. They are regarded, for instance in Japan, as seven irreplaceable quality tools. They derive their name and popularity from an opinion saying that their skilful and common use may result in solving over $90 \%$ of quality problems. One can distinguish the following ones (Bujak, Puszko, 2012, p. 69):

- the Pareto chart - it illustrates a frequent irregularity (of aims, purposes). The irregularity indicates that a relatively small number $(20 \%)$ of reasons determines a considerably high contribution (80\%) of results. Thus, the hierarchy of problems results in dealing with problems in such a way which brings the most palpable effects,

- the Ishikawa diagram - it allows to observe, in a graphical form, mutual connections between the roots of problems or tasks and conditions related to a given concept as to solving the said problem,

- bar charts, line charts and pie graphs - supplementing a dependence, e.g. a line dependence by showing an influence of the third parameter (feature) - dispersion in a point. Pie graphs are a geometrical interpretation of grades related to the weight classification and their reference level (outer circle - max. or inner circle - min.),

- the X-R, X-S check sheets - representing changeable average values of assessed goods' features and gaps or a standard deviation in a sample. They allow to observe the stable character of the production process, used both for assessing effects as well as capabilities of machinery stock,

- check sheets - they systematise values, observed in subsequent value assessments, against determined permissible variable ranges. The so-called check sheet trajectory represents exceeded upper and lower check lines,

- histograms - a representation in bar charts of an occurring feature against defined value ranges. The graphic representation of the layout and its location as to nominal values and tolerance values,

- two-diagram variables - a representation of variable tendencies of a parameter in two measurement states or interdependence of two parameters of a good (Peciakowski, 2008, p. 48).

The term quantitative research methods defines methods aimed at performing specific measurements and assessing particular phenomena. The research as such does not necessarily allow to acquire a new knowledge. That is why scientific research should not be based solely on quantitative research methods (Kirk, Miller, 1996, p. 97). Quantitative research should be used when researchers believe themselves to have 
understood the nature of a phenomenon and factors which determine the said phenomenon. Hence, a following conclusion can be drawn - quantitative research methods are used by researchers to determine the scope of phenomena, in which the researchers have a remarkable insight. The inference based on quantitative research results is determined by mathematical statistics methods; it allows to translate the results obtained from a research sample into the general population (Kowalewska, 2009, p. 212).

Quantitative research involves quantitative characteristics and analysis of information, phenomena or processes. The research is often presented by means of various breakdowns and calculations, with a consideration given to such disciplines as descriptive or mathematical statistics.

The following methods are classified as model quantitative methods: statistical analysis, SPACE, network methods, the Delphi method.

\section{Statistical analysis}

Many sciences, including management sciences, deal with observing the surrounding reality or use experiments to confirm the theories being subject to research. In economics and management sciences the research relates, in most cases, to the reality of existing companies as well as particular areas of activity (systems, subsystems). Taking into consideration that an enterprise is a set of various elements that co-exist and perform together various functions, aims and tasks. The quantitative analysis of the enterprise often requires to collect a great amount of data, and to analyse and interpret them. In order for the process to be feasible, it is necessary to put together a relevant set of tools which allow to analyse a large set of data. The tools in question are elaborated on the basis of knowledge of statistics.

Nowadays the statistics has been regarded as a branch of science that encompasses almost all areas of people's activity. Collecting figures, so called data, their analysing, synthetizing and presenting in various ways have never been easy. Thus, it is necessary to gather tools that allow for such actions. The tools are referred to as statistical methods, whereas the most popular method is a statistical analysis.

The aim of the statistical analysis is to draw generalisations about analysed information, and acquire the greatest possible knowledge from the collected data. Such understanding of the notion of the statistical analysis implies that the statistics can be viewed as a knowledge on reasoning, in which primary and synthetic data are to be employed in the reasoning process based on principles of the probability theory and inductive reasoning theory. 
Statistical inference leads from data or a sample to population. The population is a kind of universe; it may be defined as a general community, i.e. a set of all measurement results or an aggregate of elements to be subject to research and to be found in the researchers' areas of interest. The sample is a sub-set of populations that were selected by a researcher in a determined way. The sample should be a representation of the population. A research sample should be taken randomly, which means that each possible sample of $n$-elements should have the same opportunity to be chosen. The sample selected in the said way is called a simple random sample or a random sample. The sample is then subject to a study, while its results are generalised against the general population.

Another essential issue connected with the statistical research is the necessity to systematise the acquired results. The systematisation should be based on scales of measurement. The systematisation involves assigning digits or symbols to objects (e.g. phenomena), in accordance with specific rules and principles (Bielecka, 2005, p. 94). The said assignment process is called a scale of measurement. Scales of measurement are classified according to the following hierarchy, from "the weakest" to "the strongest" (Stevens, 1946, pp. 677-680): nominal scale, ordinal scale, interval scale and ratio scale.

Having determined the scale of measurement for the statistical test, it is possible to pursue subsequent steps related to statistical calculations. The aim of the calculations is to translate the results into the general population. The area which covers the above-mentioned issues is the statistical inference. The statistical inference is a branch of statistics; its task is to generalise the research results and also to estimate errors that result from the employed generalisations. In order to obtain reliable results, one needs to maintain a proper approach to analysing and interpreting the research findings. It is therefore necessary that the research is based on relevant empirical data. Equally important is to formulate relevant research hypotheses and verify them. Statistical inference consists of activities carried out by the researcher, connected with the rejection or acceptance of a hypothesis.

\section{Network methods}

Skilful planning of various enterprises has been currently one of the most essential tasks of managers in organisations. Unfortunately, the planning tends to be complicated and time-consuming. What is more, it may require considerable financial expenditures. In order to optimise the plan as to the time and involved expenditures, it is necessary to skilfully elaborate relevant methods for planning of undertakings. Methods that facilitate such optimisation are called network planning methods. The said methods, used to lower the costs and reduce the durations of various actions, allow to adopt such action plans. The action plans allow to determine these activities which need to be analysed in detail. The network planning methods allow to select an 
optimal action plan for a given company. Thus, it is possible to determine the order for particular tasks to be executed. The network planning methods also help to: (Adam, Ebert, 2009, Krawczyk 2001):

- $\quad$ set commencement and termination dates for particular tasks,

- $\quad$ set the time for performance of the entire undertaking,

- $\quad$ select the so-called "critical actions”, i.e. actions that affect the performance deadline of the whole undertaking,

- $\quad$ allocate production means, being at the disposal of a company, e.g. labour force, machines to particular tasks.

The most important methods include, among others, the CPM and PERT (Adam, Ebert, 2009, Krawczyk 2001) Methods. The CPM Method is also called the critical path method. The method is used to establish a schedule for projects that are characterised by fixed time for execution of the tasks. On the other hand, the PERT method (Program Evaluation and Review Technique), being a technique used to evaluate and review a program, has been used to establish schedules for projects that take into account a random character of the time for the execution of the constituent tasks.

\section{The PERT Method (Program Evaluation and Review Technique)}

The PERT method is a method allowing to plan and control the execution of an undertaking. The method emphasizes that the duration time of extraordinary or nontypical activities is not established deterministically. The PERT method is based on an assumption that the durations are random variables. Such an approach to the durations of the project tasks allows to benefit from statistical methods in order to assess the risks related to the timely completion of tasks, and determine the probability of completing them within a given time (Trocki, Grucza, Ogonek, 2003, Brandenburg, 2002, p. 211).

The PERT Method was elaborated to evaluate approximate durations for the tasks to be executed, and to determine the probability of completing the tasks within the time as required by the researchers. The PERT Method was mainly designed for the sake of costly projects where the level of risk is high. Nowadays, the method can be applied to a smaller scale. The PERT Method, alike the CPM Method, shows a project as a network diagram, i.e. a directed graph. It is aimed at establishing a critical path for the project. In order to complete a project by means of the PERT method, one needs to (Adam, Ebert, 2009, Krawczyk, 2001):

- define all activities included in the undertaking, 
- establish time-related succession of activities included in the undertaking,

- estimate the duration of each activity included in the undertaking,

- determine a critical path,

- elaborate a schedule of the undertaking,

- assess and implement corrections, compliant with actual status.

As a result of employing the PERT method for planning undertakings in a company, one may achieve the following advantages (Trocki, Grucza, Ogonek, 2002, p. 211):

- opportunity to present a project in the form of a graph. The graphical representation of the projects is much more comfortable and much clearer, as opposed to, for instance, bar charts,

- in order to prepare a graph, one needs to carefully analyse the whole undertaking, thus, one is sure that the whole undertaking was meticulously planned,

- determining a critical path; it allows to identify project-related problems and obstacles as early as at the planning level - it is possible to undertake corrective actions,

- it allows to draw comparisons as to costs and duration of various methods of executing projects and obtaining subsequent results.

However, the PERT method presents some limitations, including (Adam, Ebert, 2009, Krawczyk, 2001):

- the method does not allow to determine types of risks that may appear as well as their scales, categories and symptoms. This results from the fact that the method focuses but on the duration of a task,

- the use of method while working on a large project is connected to being obliged to cover high costs,

- computational accuracy and precision are dependent on abilities of staff performing the said computation operations. 


\section{The CPM Method}

The CPM Method is also called the critical path method. The method allows to plan and control an undertaking, with a special consideration given to its length and opportunity to predict its results which might be generated by changes to the course of project tasks. The CPM Method is aimed at determining the shortest time possible to complete the undertaking and allow for its proper course. The CPM Method assumes that the time for the execution of particular undertaking-related tasks is determined, i.e. firmly established (Bałuk, Lenard, 1999).

The CPM Method and PERT Methods are similar to each other as to obtained results and adopted approaches to such variables as financial and material resources, as well as machines, devices, and human potential. The latter is treated as non-changeable data during the execution of the undertaking. The most essential common feature of these methods is to determine a sequence of tasks (network of activities) that reduce the undertaking's completion time and that are referred to as a critical path. The main difference between these two methods is the way in which a network graph is designed. In order to show grids of links between tasks, which tasks need to be executed in order to complete a given project, the network methods should make use of graphic symbols, depicting such notions as: an activity and an event. The activity might be defined as a partial activity of an undertaking, using the time and means such as: labour, materials, financial means, etc. The activity is presented by means of a symbol - an arrow. Above the arrow one can find the activity's duration time.

On the other hand, an event might be defined as a moment in which a given activity is supposed to start. The event depends on whether a prior event on the dependency graph was completed. Only the first event has no prior event. The event is marked with a symbol of a circle. The events are numbered with natural numbers. The CPM Method is structured in defined stages. The stages are as follows (Kucharski, 2016):

- a breakdown of activities involved in the completion of a project.

- durations of particular activities being executed.

- determining mutual links between the activities.

- determining the beginning and completion dates for particular activities.

- determining means that are necessary to complete given activities.

- determining costs related to the completion of particular activities.

The CPM Method is a method used to enhance the completion of activities. It is used most often to plan repeatable projects. The method is a very popular tool for planning 
and controlling of the project implementation in Poland. It features the following advantages(Kucharski, 2016) :

- it allows to plan and control the project implementation,

- it allows to predict results of changes to the project implementation,

- it allows to detect bottlenecks in the project implementation,

- it allows to compare IT tools, such as: MS Project,

- it allows to evaluate the duration of particular activities.

The method, however, presents some limitations (Kucharski, 2016):

- the method is connected with a necessity to spend a lot of time and money on preparing a completion plan for a given undertaking,

- the method does not automatically solve any questions,

- the method does not deal with qualitative problems.

It is possible that in the network methods there might be some actions that would not ensue any expenditures. The activities are known as apparent activities.

\section{The Delphi method}

Growing complexity and dynamics of the development of management sciences brought about requirements connected with methodological eclecticism, management poly-methodology (Sułkowski, 2011, pp. 33-37), as well as methodology triangulation (Stańczyk, 2011, pp. 79-84). The Delphi method was created when the abovementioned requirements, advocating the necessity to make use of various, selfcorrecting and self-verifying research methods, were met (Denzin, 2009, pp. 297-300).

The Delphi method is regarded as a repetitive way of collecting, elaborating, analysing and interpreting of empirical data. The method is aimed at obtaining completely and maximally justified answers to posed research questions (Nowak, 2008). The Delphi method can be also described in the source literature as a method or technique based on a structured process of group communication. The process, involving a group of independent persons, is aimed at finding a solution to a given question (Linstone, Turoff, 2002, p. 3). The name of the method was derived from the ancient Greece and the Oracle of Delphi (Matejun, 2012, pp. 173-182). A priestess at the Oracle (Pythia) predicted the future by being filled by the spirit of Apollo. Nowadays, the Delphi 
method revolves around more rational and scientific grounds. However, the method is still connected with predicting of the future (Stone Fish, Busby, 2005, p. 240). The currently applied Delphi method was started in early 1950s. It is when three pillars, underlying the method, were established (Fischer, 1978, p. 64):

- knowledge, confirmed with irrefutable evidence,

- speculation; one lacks evidence to prove it,

- opinions, confirmed by just some evidence.

Taking into account the above-mentioned prediction-related grounds, one can conclude that the Delphi method has been used to obtain opinions from experts. On the basis of the said opinions, the chances of solving problems and determining the nearest future are developed.

\section{Triangulation of methods in the research process}

In social sciences, it is a mistake to employ, in the course of one's research, just one research method, typical for a given research subject. M. Kostera claims that „a choice is always a derivative from a research problem, i.e. depending on a subject matter of the research, a decision as to the best way of researching is taken" (Kostera, 2003, p. 97). Employing a single research method in the research process makes the reliability of the research findings doubtful. Furthermore, if the literature research was used as a research method, then the scientific and research papers would be of strictly theoretical character. In order to make the research reliable, one should use a socalled triangulation of research methods. The said triangulation allows to: analyse a phenomenon in a broader sense, improve the quality of research being conducted, decrease any measurement errors.

In the most general sense, triangulation means the use of various research methods in order to obtain coherence between cognition and findings (Czarzasty, 2000, p. 98). The main purpose of triangulation, established by D. Campbell and D. Fieske, is to combine different research methods in one research study (Campbell, Fiske, 1959, pp. 81-105). In other words, triangulation means applying two or more independent processes aimed at measuring a given phenomenon so that uncertainty of research findings is decreased (Webb, Campbell, Schwartz, Sechrest, 1966, Greene, Caracelli, Graham, 1989, pp. 255-274). Triangulation should not be treated in a freely way, the applied methods should not be randomly selected (Sułkowski, 2005, p. 107). Triangulation is divided into four types (Denzin, 1970):

- data triangulation - involves using data from independent sources, 
- investigator triangulation: participation in research conducted by a group of observers,

- theory triangulation: involves using various theories to interpret a single set of data,

- methodological triangulation: involves using several research methods to examine a single problem/phenomenon.

Each of the above-mentioned triangulation types allows to retain some objectivity and reliability of reasoning. It needs to be emphasised that the use of triangulation in research leads to generalisation of analytical and not statistical character, hence it is not possible to apply findings to the entire population - i.e. to generalise conclusions (Konecki, 2000, pp. 85-98). Triangulation of data and methodological triangulation are more often used in the research than the investigator or theory triangulation (Kostera, 2003, p. 98). Method and data triangulations allow to gather a broader, so-called field material and a more reliable foundation for drawing conclusions (Repstad, 87/88, p. 97). Within the scope of triangulation, some related complementing methods are combined. They are employed in four groups (Konecki, 2000, p. 133, Kostera, 2003, pp. 101-156): observations, interview, text analysis and artefact analysis.

When using triangulation one needs to prudently select research methods to be employed.

L. Krzyżanowski maintained that „A consequence of the fact that sciences on organisation management derive, broadly and greedily, skilfully in most cases, although sometimes not enough critically, from methodological tools of numerous and diverse supporting research disciplines, is their methodological underdevelopment, i.e. a lack of forged discipline-related (or branch-related) detailed methodology" (Krzyżanowski, 1999, p. 283).Triangulation may be characterised as a process of embodying a given phenomenon, analysed in social world. The said embodying means the application of following three processes (Konecki, 2000, pp. 81, 95):

- drawing up a research report, requiring that findings and quantitative data be indicated,

- employing research procedures, dependent on the applied research method,

- performing analyses, with a consideration given to necessary analytical procedures.

Although triangulation is one of heuristic research tools (Konecki, 2000, p. 85), when applied, one method needs to be the basic one, whereas the others should complement it. If a researcher opts for combining, in his/her research, qualitative and quantitative methods, he/she needs to apply the methods in a correct way. Hypothetically, qualitative research may be a perfect starting point for using statistical 
methods, and vice versa (Kostera, 2003, pp. 97-98). The use of triangulation is also promoted by requirements as to conducting scientific research, i.e. (Kostera, 2003, pp. 97-98):

- reliability: opportunity to obtain again the same results,

- credibility: conformity of results with their qualitative descriptions,

- authenticity: defining a probability of occurrence of phenomena under scrutiny,

- opportunity to draw generalisations.

In the area of economics and management sciences, there exists a growing problem of a coherent, i.e. a unanimous theory. Science uses the word "scientific" for those theories that were confirmed by other researchers. Is that really possible in the management sciences which are characterised by the turbulent environment? J. Ziman claimed that "facts and scientific theories should undergo a process of critical reviews and trials made by other competent and unbiased persons; they also should be convincing enough to become generally accepted" (Ziman, 1968, p. 41). One can therefore claim that since centuries science has been heading to obtain unanimity in the broadest sense. Due to the foregoing, the statement by J. Bogdanienko: „The most crucial postulate should be to refrain from disclosing one's own insufficiently grounded views to the public. (...) Rush for glory should be supressed by an objective not to publish one's thoughts prematurely" (Bogdanienko, 2010, p. 175) seems to be reasonable. J. Ziman accurately stated that ,....a complete unanimity is nothing but a death of science. Were all researchers unanimous, the science would stop developing" (Szymborski, 1986, p. 32).

A crucial element in the management sciences is to accept a thesis saying that it is impossible to accept one widely correct theory in the organisation-related sciences. Attempts to find one universal theory are sheer waste of time. The thesis above may be backed by the following arguments(Szymborski, 1986, p. 32):

- words by M. Hatch. She claimed that explaining multidimensional problems is not possible when based on a single scientific opinion; the management-related science as such is a complex problem (Hatch, 2002, Schultz, Hatch, 1996),

- opportunity to achieve a determined target with the help of numerous means,

- a diversity of solution is a result of people's subjective approaches to the said solutions,

- it is not possible to establish one universal theory which could explain main management-related problems in each organisations, since the said problems are too diverse, multi-dimensional and quickly changeable over time. 


\section{Conclusion}

Quantitative research, based on the hypothetical-deductive model, employs experimental methods and quantitative scales to verify hypotheses and obtain generalised results for the entire population. Quantitative methods can derive from the qualitative research carried out earlier, strengthen the basic qualitative research and organize data for the sake of further presentations. A properly elaborated research process allows to obtain scientifically valuable results. Obtaining the said scientifically valuable results also depends on the researchers' abilities to select and make use of research methods (Sudoł, 2007, p. 134). Quantitative research, despites of its great popularity, has its numerous proponents and opponents. They underline the qualities of an adopted approach, while ignoring other, different research approaches. The following paper presents but general characteristics of quantitative research and its basic features. Main areas and stages of quantitative research were determined. Selected basic methods were enumerated, which methods may be used for the sake of quantitative research carried out in the management sciences. The character of the research affects decisions as to precise designing of research, creating a research model and selecting particular research methods. In each scientific discipline there appear various theories at the same time, whereas the theories may often be mutually inclusive or mutually exclusive. Various motivation theories are a good example of this phenomenon, since they have been constantly replaced by new ones (Dolby, 1998, p. $5)$. In the world of science, an agreement is often a fruit of heated discussions (Heidegger, 2001, p. 29). This is particularly true in case of social sciences. Despite of the fact that triangulation is mostly employed to enhance the reliability of qualitative research methods used in a given research (Shah, Corley, 2006, p. 1830, Czakon, 2009 , p. 16), which methods trigger numerous questions as to the actual character of the reality being analysed (Konecki, 2000, pp. 78-85). It is connected to the field studies, data triangulation and testing of obtained results or selecting a proper research sample. It needs also to be underlined that the triangulation should act as an enhancement of reliability of quantitative methods in the research processes.

\section{References}

Adam E.E., Ebert R.J.: Productions and operations Management. Prentice Hall, New Jersey 2009.

Bałuk J., Lenard W.: Organizacja procesów produkcyjnych - materiały pomocnicze do ćwiczeń, Wyd. Politechniki Warszawskiej, Warszawa 1999.

Bielecka A.: Statystyka w biznesie i ekonomii. Teoria i praktyka, WSPiZ im. L. Koźmińskiego, Warszawa 2005.

Bogdanienko J., Etyka w badaniach naukowych, w: Osiągnięcia i perspektywy nauk o zarządzaniu, praca zbiorowa pod red. S. Lachiewicza i B. Nogalskiego, Wolters KLuwer, Warszawa 2010. 
Brandenburg H.: Zarządzanie Projektami, Wydawnictwo Akademii Ekonomicznej w Katowicach, Katowice 2002.

Bujak A., Puszko K.: Narzędzia doskonalenia jakości w budownictwie, [w:] Forlicz S. (red.): Zastosowanie metod ilościowych w ekonomii i zarządzaniu. CEDEWU.PL, Warszawa 2012.

Campbell D.T., Fiske D.W.: Convergent and Discriminant Validation by the Multitrait-Multimethod Matrix. Psychological Bulletin 1959, vol. 56.

Czakon W.: Mity o badaniach jakościowych w naukach o zarządzaniu. "Przegląd Organizacji" 2009, nr 9.

Czarzasty J.: Triangulacja - refleksje z badań. [w:] Zamazane granice. Etnografia przedsiębiorstwa fińskiego w Polsce, praca magisterska, Wydział Zarządzania Uniwersytetu Warszawskiego, Warszawa 2000.

Denzin N.K.: The Research Act: Theoretical Introduction to Sociological Methods. Aldine Publishing Co., Chicago 1970.

Denzin N.: The Research Act: A Theoretical Introduction to Sociological Methods. Transaction Publishers, 2009.

Dolby U.: Niepewność wiedzy. Obraz nauki w końcu XX wieku. Wydawnictwo Amber, Warszawa 1998.

Fischer R.G.: The Delphi Method: A Description, Review, and Criticism. Journal of Academic Librarianship, vol. 4, nr 2/1978.

Gerstmann S.: Podstawy psychologii konkretnej. Wydawnictwo Naukowe PWN,' Warszawa 1987.

Greene J.C., Caracelli V. F., Graham W. F.: Toward a Conceptual Framework for Mixed-Method Evaluation Design. Educational Evaluation and Policy Analysis 1989, vol. 11, no. 3.

Hatch M.A.: Teoria organizacji. Wydawnictwo Naukowe PWN, Warszawa 2002.

Heidegger M.: Zasada racji. Wydawnictwo Baran i Suszczyński, Kraków 2001.

Janesick V.: The Dance of Qualitative Research Design. Metaphor. Methodolatry and Meaning. [in:] Handbook of Qualitative Research, eds. N.K Denzin, Y.S. Lincoln, Sage, New Delhi- Thousand Oaks-London 1994.

Kirk J., Miller M.: Reliability and Yalidity in Qualitative Research, Sage, London 1996.

Krawczyk S.: Metody ilościowe w planowaniu (działalności przedsiębiorstwa).Tom I, C.H. Beck, Warszawa 2001.

Konecki K.: Studia z metodologii badań jakościowych. Teoria ugruntowana. Wydawnictwo Naukowe PWN, Warszawa 2000.

Kostera M.: Antropologia organizacji. Metodologia badań terenowych. Wydawnictwo Naukowe PWN, Warszawa 2003. 
Kowalewska A. (red): Raport końcowy, badanie firm rodzinnych, Warszawa 2009.

Krzyżanowski L. J.: O podstawach kierowania organizacjami inaczej: paradygmaty, metafory, modele, filozofia, metodologia, dylematy, trendy. Wydawnictwo Naukowe PWN, Warszawa 1999.

Kucharski A.: llościowa analiza sieci czynności, materiały do ćwiczeń, wersja elektroniczna:http://aqcharski.w.interia.pl/pliki/sieci_czynnosci/ilosc_siec_czynnosci_wyk_razem. pdf, 15.07.2016.

Linstone H.A., Turoff M.: Introduction. (w:) Linstone H.A., Turoff M. (red.): The Delphi Method. Techniques and Applications, Murray Turoff and Harold A. Linstone, 2002.

Matejun M.: Metoda delficka w naukach o zarządzania. (w:) Kuczmera-Ludwiczyńska E. (red.): Zarządzanie w regionie. Teoria i praktyka, Oficyna Wydawnicza SGH, Warszawa 2012.

Nowak S.: Metodologia badań społecznych. PWN, Warszawa 2008.

Peciakowski E.: Narzędzia jakości. „Problemy Jakości”, marzec 2008.

Płoszajski P.: Między refleksją a działaniem. Dylematy praktycznej teorii zarządzania. Zakład Narodowy im. Ossolińskich - Wydawnictwo, Wrocław 1985.

Repstad P.: Narthet och distans: Kvalitativa metoder I samhdllsvetenskap. Student litteratur, Lund $1987 / 1988$.

Shah S., Corley K.: Building Better Theories by Bridging the Qualitative-Quantitative Divide. "Journal of Management Studies" 2006, vol. 43, no. 8, s. 1830.

Schultz M., Hatch M.J.:I ii ni n/i with multiple paradigms: case of paradigm in organizational culture studies, „Academy ofl Mniumomniil. Review 1996, vol. 21, No. 2.

Stańczyk S.: Triangulacja - łączenie metod badawczych i urzetelnienie badań, [w:] Czakon W. (red.): Podstawy metodologii w naukach o zarządzaniu. Oficyna Wolters Kluwer business, Warszawa 2011.

Stevens S.S.: On the theory of scales of measurement. Science, Vol. 103, No. 2684, 1946.

Stone Fish L., Busby D.M.: The Delphi Method, [w:] Sprenkle D.H., Piercy F.P. (red.): Research Methods in Family Therapy. The Guilford Press, New York 2005.

Sudoł S.: Nauki o zarządzaniu. Węzłowe problemy i kontrowersje. Dom Organizatora TNOiK, Toruń 2007.

Sułkowski Ł.: Rozwój metodologii w naukach o zarządzaniu, [w:] CzakonW. (red.): Podstawy metodologii w naukach o zarządzaniu. Oficyna Wolters Kluwer business, Warszawa 2011.

Sułkowski Ł.: Epistemologia w naukach o zarządzaniu, Polskie Wydawnictwo Ekonomiczne, Warszawa 2005.

Szałkowski A.: Kształtowanie funkcjonalnych stosunków pracy. Zakład Narodowy im. Ossolińskich Wydawnictwo, Wrocław 1997. 
Sztumski J.: Wstęp do metod i technik badań społecznych. Wyd. Śląsk, Katowice 2005.

Szymborski K.: Oblicza nauki. Wydawnictwo Iskry, Warszawa 1986.

Trocki M., Grucza B., Ogonek K.: Zarządzanie Projektami, Polskie Wydawnictwo Ekonomiczne, Warszawa 2003.

Webb E.J., Campbell D.T., Schwartz R.D., Sechrest L.: Unobtrusive Measures: Nonreactive Measures in the Social Sciences. Rand McNally, Chicago 1966.

Ziman J.M.: O problemach społeczeństwa nauki. PWN, Warszawa 1968. 